\title{
MENULIS ITU MENYENANGKAN
}

\author{
Syamsidah \\ syamsidah_april@yahoo.com \\ TK Arum Puspita Ciren Triharjo Pandak Bantul
}

\begin{abstract}
Abstrak
Menulis merupakan aktifitas menuangkan ide berupa pengalaman nyata atau cerita rakyat yang disebut dengan tulisan non fiktif dan cerita khayalan yang disebut dengan tulisan fiktif. Menulis membutuhkan beberapa persiapan antara lain motivasi, dukungan sahabat atau bisa bergabung dalam komunitas penulis serta alat tulis seperti komputer. Beberapa aspek tersebut merupakan komponen dalam persiapan internal, persiapan eksternal dan persiapan peralatan. Cara menulis perlu diketahui penulis pemula agar menulis menjadi aktifitas yang menyenangkan. Langkah yang perlu dilakukan yaitu memulai menentukan jenis tulisan fiksi atau nonfiksi kemudian membuat kerangka atau peta konsep agar hasil tulisan bisa berkualitas dan dapat dipublikasikan. Hasil tulisan yang dapat dipublikasikan dalam bentuk buku maupun jurnal dapat memberi keuntungan berupa royalti dan menambah angka kredit untuk kenaikan pangkat.
\end{abstract}

Kata Kunci: Menulis, Publikasi

\section{Abstract}

Writing is an activity of pouring out ideas in the form of people's experience or story - or so called as non-fiction, and fantasy or called as fiction. It needs some preparations to start writing, such as stationeries like computer, and also motivation which can be in the form of support from friends or aim to join some writer communities. Those aspects are included as equipment, external, and internal preparation. Beginners need to be aware of writing procedures so that writing can be a fun activity. Steps that should be done are deciding the type of writings, fiction or non-fiction, and then developing the framework or mind map to make the writings qualified to be published. The published writings, either books or journal, can bring profit like royalty and also credit for promotion.

Keywords: Writing, Publication

\section{Pengertian Menulis}

Menurut Salman El Bahry (20: 2014) dalam bukunya yang berjudul "asyiknya bekerja sebagai penulis " menulis merupakan pekerjaan dalam menggoreskan pena untuk menuangkan gagasan berupa fiksi dan non fiksi lewat bahasa tulis. Jika yang ditulis itu merupakan ceritera / pengalaman nyata baik yang dialami sendiri atau dialami orang lain kemudian kita tulis itu dinamakan tulisan non fiktif atau nyatanyata terjadi. Tetapi jika yang kita tulis merupakan khayalan itu dinamakan fiksi.

\section{Persiapan Menulis}

Dalam menulis ada tiga hal yang perlu dipersiapkan yaitu :

- Persiapan Internal

Persiapan internal yakni persiapan yang datang dari diri sendiri. Persiapan ini hukumnya fardhu 'ainbagi setiap orang yang akan menulis. Yang termasuk persiapan internal yakni :

Pertama, niat dan kerja keras. Untuk dapat menulis tidak diperlukan syarat yang jlimet seperti kepinteran, seorang sarjana, berpendidikan tetapi 
yang dibutuhkan adalah niat dan semangat untuk kerja keras.

Seperti Penulis Hamka, beliau secara formal hanya berpendidikan ditingkat Sekolah Dasar, tetapi punya niat dan semangat kerja keras sehingga dapat menghasilkan lebih dari 100 judul buku.

Kedua, dapat membaca dan mampu menulis. Bisa membaca disini bermakna luas, membaca dengan panca indera ditambah lewat insting, perasaan, serta imajinasi. Untuk bisa menulis harus bisa membaca teks tertulis dengan indera penglihatan, juga dapat membaca fenomena kehidupan alam. Hal ini sangat urgen ketika menulis fiksi agar tidak terasa kering kerontang.

Ketiga, memiliki pengetahuan. Anda ingin menulis tetapi tidak mempunyai pengetahuan tentang apa yang akan ditulis, sama saja bohong. Keinginan anda tidak mungkin terwujud. Bagaimana cara memperoleh pengetahuan ? banyak jalan! Bisa dengan membaca, bertanya, mengamati objek, berfikir, kursus, kuliah, pelatihan dan lain-lain.

Keempat, bersedia berlatih. Mampu menulis bukan soal bakat atau keturunan. Banyak penulis bukan keturunan dari penulis, atau sebaliknya. Menulis adalah proses berlatih, berlatih dan berlatih.Tidak seorangpun lahir langsung bisa menulis atau menjadi penulis.

Kelima, berani mempuplikasikan. Katakanlah naskah sudah jadi, maka langkah selanjutnya berani menerbitkan. Jangan khawatir kalau naskah belum memikat penerbit. Itu perkara biasa.

Keenam, motivasi. Motivasi bisa berasal dari diri sendiri atau orang lain. Apa yang memotivasi anda untuk menulis, ingin terkenal, ingin berbagi ilmu, ingin meluapkan perasaan, ingin mengasah pikiran, ingin mendapatkan nilai angka kredit bagi guru, atau ingin mendapatkan penghasilan itu boleh-boleh saja dan sahsah saja.

- Persiapan Eksternal
Setelah persiapan internal mantab, maka persiapan berikutnya adalah persiapan eksternal. Yakni persiapan pendukung dari luar, seperti dukungan dari keluarga dan sahabat. Keinginan untuk menulis mendapat dukungan penuh dari keluarga, karena bagaimanapun keluarga adalah orang yang telah berjasa dalam hidup kita. Jangan sampai karena asyik menulis menjadi lupa pada keluarga, sehingga dapat menjadikan prahara dalam rumah tangga. Sahabat juga dapat memberikan dukungan dalam menulis. Kalau perlu bergabunglah dalam sebuah forum, komunitas, pelatihan atau yang lain.

Jika telah mendapat dukungan dari keluarga, lingkungan juga perlu diperhatikan ketika akan menulis. Lingkungan yang nyaman, tenteram, asri dapat menjadikan kenyamanan dalam menulis sehingga dapat mudah berimajinasi, menelorkan gagasan dalam menulis.

- Persiapan peralatan

Secara tradisional peralatan yang diperlukan dalam menulis berupa pena dan kertas. Idialnya memang dalam menulis menggunakan peralatan seperti komputer atau lap top sehingga ketika akan dipublikasikan lewatpenerbit, penerbit tidak mengetik ulang.

\section{Cara menulis.}

Setelah persiapan matang mulailah untuk menulis. Sebelum menulis tentukan dulu jenis fiksi atau non fiksi yang akan ditulis. Langkah yang dilakukan ketika akan menulis :

- Tentukan Jenis fiksi atau non fiksi.

- Ada yang menentukanjudul dulu tetapi ada juga judul dibuat setelah semua tulisan selasai ditulis, bagi pemula lebih enak menentukan judul dulu.

- Buat kerangka atau peta konsep untuk mempermudah dalam menuangkan ide/gagasan.

- Mencari buku referensi sebagai pengetahuan yang harus kita miliki 
untuk membantu menumbuhkan ide dan gagasan.

- Tulislah apa yang mau ditulis. Ketika menulis, terus menulis sampai selesai satu tema, jangan menulis dua baris berhenti kemudian di baca. Tetapi selesaikan dulu satu tema, baru berhenti untuk dibaca. Apa yang tidak sesuai baru direvisi. Kalau sebaris dibaca kemudian direvisi, tidak akan selesai-selesai serta tidak akan nyambung-nyambung.

- Setelah semua kerangka dijabarkan, baca keseluruhan, baru anda akan menemukan dimana ketidak nyambungnya antara alinea yang satu dengan alinea berikutnya, tinggal memperbaharui.

- Gunakan bahasa yang sesuai dengan jenis tulisan yang kita tulis, misal jika kita menulis tentang ceritera untuk anak-anak, bahasa yang digunakan bahasa anak, sederhada, tidak menggunakan bahasa ilmiah.

- Jika telah menguasai komputer, revisi tulisan lebih enak daripada ketika menulis secara manual.

\section{A. Keuntungan menulis}

Banyak keuntungan yang diperoleh dalam kita menulis seperti :

- Bertambah pengetahuan, karena sebelum menulis kita banyak membaca, bertanya, mengamati objek

- Dapat menuangkan gagasan yang mungkin dapat menularkan ilmu pada orang lain yang membacanya.

- Bagi guru dapat menulis apalagi dapat dipublikasikan dalam bentuk buku, kemudian diterbitkan oleh penerbit, ber ISBN akan mendapatkan angka kredit, mendapat nilai dalam Penilaian Prefesi Guru atau PKG yang sekarang sedang digalakkan.
- Mendapat tambahan penghasilan jika tulisan diterima oleh penerbit untuk dipublikasikan.

- Menurut pendapat para ahli dengan menulis dapat mencegah kepikunan.

\section{Cara mempublikasikan tulisan.}

Jika tulisan telah selesai, beranikan diri untuk dapat dipublikasikan tulisan anda. Caranya tidak bosan-bosan untuk mencoba mengirim naskan ke penerbit/percetakan.

Seperti penulis lakukan, setelah penulis mempunyai beberapa karya, penulis mencoba mengirimkan naskan ke beberapa penerbit, pertama tidak ada jawaban. Penulis tidak putus asa, penulis perbaiki karya yang penulis punyadandicobalagi kebeberapa penerbit, Alhamdulillah, Tuhan mengabulkan, karya penulis ada yang diterima oleh penerbit.

Yang perlu diingat, ketika kita akan mengirimkan naskah, harus kita ketahui dulu penerbit yang akan kita kirimi bergerak di jenis apa, jenis anak-anak, jenis tentang ilmiah, tanaman atau umum. Seperti juga toko, kalau toko penjual buku tentu saja tidak mau jika kita tawari buahbuahan.

Ada penerbit yang menerima naskan dan kontrak putus, artinya setelah naskan diterima dan disetujui untuk diterbitkan, penulis mendapat honor sekali sebagai penulis, naskan direvisi oleh editor, kemudian diterbitkan dan dipasarkan, tetapi penulis tidak ada bagian sebagai royalti. Penulis akan mendapat 5 eksemplar buku yang telah terbit dengan gratis. Penulis juga dapat menjualkan buku karyanya dengan mendapat potongan harga. Tetapi ada juga penerbit yang memberikan honor sebagai penulis, diterbitkan gratis, masih mendapat royalti. Ini bagi penulis yang sudah betul-betul profesional.Tetapi ada juga penerbit yang mau menerbitkan jika ada biaya dari editing, lay out dan lain-lain. Semua biaya dan pemasaran ditanggung penulis. 
Motivasi saya ingin menulis.

Meskipun penulis berprofesi sebagai guru Taman Kanak-kanak, dimana banyak orang beranggapan bahwa guru TK bisanya nyanyi dan tepuk tangan, tetapi penulis bangga, dengan profesi sebagai Guru TK banyak Ide dan gagasan yang penulis tuangkan dari pengalaman menjadi guru TK, sehingga menjadi sebuah karya/buku.

Yang memotivasi penulis untuk menulis membuat buku yang pertama penulis ingin membuktikan bahwa Guru TK juga mampu menulis. Yang kedua, ingin memiliki karya buku yang ber ISBN sehingga mendapat angka kredit untuk Jabatan guru. Ketiga, ternyata menulis itu menyenangkan. Kalau sudah mulai menulis, semua gagasan, ide , gambarangambaran langsung keluar, sehingga menjadi lancar dalam menuangkan kedalam tulisan, kalau sudah menulis, lupa segala beban dalam kehidupan sehari-hari, lupa kalau punya hutang, lupa kalau hati sumpeg, apalagi ingat honor sebagai penulis, wah menjadi semangat sekali.

Pertama kali penulis karyanya diterima penerbit dan akan diterbitkan, penulis menerima honor Rp 300.000; luar biasa senangnya. 28 halaman mendapat honor 300 ribu rupiah. Kalau dilihat nilai nominal mungkin kecil ya, tetapi penulis sangat senang sekali, meskipun kontrak putus, karena penulis dapat mempunyai buku yang ber ISBN, penulis mendapat angka kredit, lumayan nilai 3, jika dibaca banyak orang penulis mendapat pahala amal jariyah. Buku kedua dan seterusnya yang diterima penerbit sudah lumayan honornya, bisa untuk berbagi dengan anakanak.

Kapan penulis melakukan kegiatan penulis? Karena banyaknya tugas guru, pertama dulu, penulis menjadwalkan setiap malam minggu dan hari minggu khusus untuk menulis, tetapi sekarang tidak, dimana ada keinginan menulis meskipun jam 1 malam yang tetap menulis, bahkan sekarang banyak di jam-jam habis tengah malam. Tetapi penulis belum pernah dan jangan sampai menulis pada jam mengajar, kita harus dapat membedakan antara kepentingan pribadi dan kedinasan.

Penulis dapat membuat karya bukan karena penulis keturunan penulis, bukan, tetapi juga dari belajar. Pertama penulis mengikuti pelatihan bersama bapak Ahmad Bahar, Bapak Kasimun, Bapak Toto Sudarto selama 6 minggu, setelah itu sampai sekarang penulis bergabung dengan teman-teman pecinta menulis di KAPULAGA, Keluarga Penulis Lintas Generasi Jogja. Setiap dua bulan sekali mengadakan pertemuan, silaturahmi kerumah-rumah anggota. Anggotanya beragam ada yang masih imut-imut usia 19 tahun, ada yang sudah usia senja 85 tahun, ada mahasiswa, pengusaha, buruh, tapi ada juga dosen, dosen TK juga ada lo. terbit :

Buku karya penulis yang telah

1. Dua model PenelitianTindakan Kelas sebagai reverensi Guru TK (Diandra Kreatif ISBN. 978-602-1638-77-4 Tahun 2014)

2. Ceritera Tradisi : Tradisi Bulan Syak Ban(Diandra Kreatif ISBN. 978-6021638-78-1 tahun 2014)

3. Ceritera Religi : Idul Fitri telah Tiba (Diandra Kreatif ISBN. 978-6201638-79-8. Tahun 2014)

4. Ceritera Religi : Pak Surya yang dermawan (Diandra Kreatif ISBN. 978-602-1638-80-4. Tahun 2014)

5. Saat pertama masuk sekolah (Ceritera anak. Diva Pres. ISBN. 978-602-255658-9. Tahun 2014)

6. 100 Permainan Untuk Anak Paud(Pedoman Guru. Diva Pres. ISBN. 978-602-7695-65-8 tahun 2015)

7. Bulan kedua aku sekolah(Ceritera anak. Diva Pres. Proses)

8. 57 Permainan Kooperatif untuk mengembangkan kecersana Interpersonal(Pedoman Guru. Diva Pres. Proses) 
9. 50 permainan Matematika untuk anak (Pedoman Guru Wahyumedia.Proses)

10. Jurnal Pendidikan Anak UNY ISSN. 2302-6804 Volume II edisi I Juni 2013

11. Jurnal Pendidikan Anak UNY ISSN. 2302-6804 Volume III edisi I Juni 2014

12. Jurnal Pendidikan Anak UNY ISSN. 2302-6804 Volume IV edisi I Desember 2014

\section{Kesimpulan}

Dari uraian diatas dapat disimpulkan bahwa untuk dapat menulis diperlukan minimal tiga persiapan, ada motivasi. Banyak keuntungan dari menulis, menulis itu menyenangkan bahkan dapt menghasilkan sehingga dapar menjadikan profesi sebagai penulis.

Menulis dapat dilakukan siapa saja. Meskipun penulis sudah sering menulis, penulis menyadari akan keterbatasan penulis, penulis cuma manusia yang tak pernah sempurna. Oleh karena itu saran dan kritik yang bersifat membangun sangat penulis harapkan.

Semoga tulisan ini menjadikan inspiratif bagi pembaca khususnya guru Taman Kanak-Kanak.

Tiada gading yang tak retak.

\section{Saran Penulis.}

Tip bagi teman-teman guru TK, pekerjaan guru TK banyak sekali, apalagi Kurikulum 13 diberlakukan dan dilaksanakan di TK, tugasnya menjadi bertambah, dari pagi sebagai Tukang Kebun, agak siang sedikit berubah menjadi guru, setelah siang kembali menjadi tenaga kebersihan, kemudian menjadi sekretaris dan administrator, tetapi kalau ada kemauan pasti Tuhan akan memberi jalan. Usahakan sehari dalam seminggu untuk berlatih menulis membuat karya tulis, dalam keadaan apapun kita bakukan satu hari misal Hari Jum at. Dalam situasi apapun di hari jumat kita harus menulis. Pastiii akan berhasil. Selamat mencoba.

\section{Daftar Pustaka}

Salman El Bahry. (2014). Asyiknya Bekerja Sebagai Penulis 